\title{
Penguatan Partisipasi Warga Banua Melalui Prinsip Ecological Citizenship Pada Program Kampung Iklim Untuk Mewujudkan
}

Ketahanan Lingkungan Lahan Basah Berkelanjutan Suroto $^{1}$, Dedy Ari Nugroho ${ }^{2}$, Rika Amelia Rafiah ${ }^{3}$. suroto@ulm.ac.id ${ }^{1}$, dedy.nugroho@ulm.ac.id ${ }^{2}, 1710112320018 @$ mhs.ulm.ac.id $^{3}$

Pancasila Program Studi Pendidikan Pancasila dan Kewarganegaraan

Fakultas Keguruan dan Ilmu Pendidikan

Universitas Lambung Mangkurat ${ }^{123}$

\begin{abstract}
Abstrak
Artikel penelitian ini memuat kajian hasil penelitian yang menitikberatkan pada upaya pemerintah dan partisipasi masyarakat dalam mengupayakan ketahanan lingkungan bagi setiap generasi, melalui keterlibatannya dalam program kampung iklim di Kota Banjarmasin. Kota Banjarmasin memiliki karaketristik alam yang didominasi kawasan sungai. Partisipasi masyarakat dan program pemerintah dalam aspek lingkungan hidup perlu dilakukan untuk menjamin keberadaan sungai agar selalu mendatangkan manfaat bagi masyarakat. Artikel hasil penelitian ini disusun menggunakan pendekatan penelitian kualitatif fenomenologi. Peneliti menjelaskan data temuan penelitian dalam rangkaian kata yang dapat menggambarkan data berdasarkan fakta. Jenis penelitian kualitatif yang digunakan dalam penelitian ini adalah jenis penelitian deskriptif fenomenologis. Hasil yang diperoleh dari penelitian yang dilakukan adalah: (1) Strategi Pemerintah Kota Banjarmasin dalam upaya penguatan Kewarganegaraan Ekologis pada Program Kampung Iklim, (2) Bentuk partisipasi yang ditunjukkan masyarakat dalam upaya penguatan Kewarganegaraan Ekologis pada Program Kampung Iklim, (3) hambatan Pemerintah Kota Banjarmasin dan masyarakat Kota Banjarmasin dalam upaya penguatan Kewarganegaraan Ekologis dalam Program kampung iklim. Hasil yang akan diperoleh dalam penelitian ini diharapkan mampu melahirkan pengetahuan bersama mengenai pentingnya partisipasi masyarakat dalam upaya membangun komitmen kontribusi pada lahan basah. Penguatan partisipasi masyarakat merupakan hal yang sangat penting untuk diupayakan Bersama, karena dengan masyarakat yang partisipatif maka aka nada banyak hal yang bisa dioptimalkan untuk kepentingan Bersama, termasuk bagaimana mengelola lahan basah. Partisipasi masyarakat harus ditingkatkan dengan sinergitas semua pihak, baik pemerintah maupun masyarakat.
\end{abstract}

Kata kunci : Ecological citizenship, Partisipasi, Pemerintah daerah

\section{Abstract}

This research article contains a study of research results that focus on government efforts and community participation in seeking environmental resilience for each generation, through their involvement in the climate village program in Banjarmasin

Peer reviewed under responsibility of Universitas Nusantara PGRI Kediri.

(C) 2021 Suroto, Dedy Ari Nugroho, Rika Amelia Rafiah

This is an open access article under the CC BY-SA license

( https://creativecommons.org/licenses/by-sa/4.0/ ) 
Jurnal PINUS: Jurnal Penelitian Inovasi Pembelajaran, 7 (1), 2021, Suroto, Dedy Ari Nugroho, Rika Amelia Rafiah

\begin{abstract}
City. The city of Banjarmasin has natural characteristics which are dominated by river areas. Community participation and government programs in environmental aspects need to be carried out to ensure the existence of rivers so that they always bring benefits to the community. This research article was compiled using a phenomenological qualitative research approach. Researchers explain research findings data in a series of words that can describe data based on facts. The type of qualitative research used in this study is a phenomenological descriptive research type. The results obtained from the research carried out are: (1) Banjarmasin City Government Strategy in an effort to strengthen Ecological Citizenship in the Climate Village Program, (2) The form of participation shown by the community in efforts to strengthen Ecological Citizenship in the Climate Village Program, (3) City Government barriers Banjarmasin and the people of Banjarmasin City in an effort to strengthen Ecological Citizenship in the Climate Village Program. The results that will be obtained in this study are expected to be able to produce shared knowledge about the importance of community participation in an effort to build commitment to contribute to wetlands. Strengthening community participation is a very important thing to strive for together, because with a participatory community, there will be many things that can be optimized for the common interest, including how to manage wetlands. Community participation must be increased with the synergy of all parties, both the government and the community.
\end{abstract}

Keyword: Ecological citizenship, participation, local government

\section{PENDAHULUAN}

Strategi pemerintah di bidang pembangunan yang dilakukan secara sentralistik, adalah satu contoh dari strategi pemerintah yang dianggap kurang reaktif terhadap kondisi masyarakat di daerah. Keadaan tersebut, dikhawatirkan dapat menyebabkan semangat masyarakat untuk mengembangkan partisipasi di tingkat daerah tidak dapat berkembang dengan baik. Rahardjo (2011), menyatakan bahwa manajemen pemerintah daerah yang dikendalikan, diatur, dan diarahkan dari pusat (top-down development), menimbulkan kecenderungan kurangnya kreatifitas dan inisiatif masyarakat dalam berkontribusi terhadap lingkungan atau pembangunan yang dilakukan. Pada prinsipnya, rakyat merupakan unsur kunci suksesnya kebijakan pembangunan di suatu negara. Melibatkan masyarakat dalam berbagai program pembangunan di daerah, merupakan strategi tepat untuk dilakukan. Senada dengan pernyataan tersebut, Johnson (2014) menyatakan bahwa partisipasi aktif masyarakat yang dilakukan di tingkat basis atau daerah, menggambarkan eksistensi sistem demokrasi yang dianut suatu negara. Partisipasi dapat dilakukan dalam berbagai bidang kehidupan, salah satunya dalam bidang pembangunan.

Partisipasi masyarakat dalam bidang pembangunan dapat dilakukan terhadap lingkungan hidup (ekologi). Pemerintah Daerah bersama masyarakat perlu meningkatkan kepedulian terhadap lingkungan hidup melalui program pembangunan yang terarah. Partisipasi 
Jurnal PINUS: Jurnal Penelitian Inovasi Pembelajaran, 7 (1), 2021, Suroto, Dedy Ari Nugroho, Rika Amelia Rafiah

dari masyarakat terhadap pembangunan lingkungan hidup (ekologi) dalam ilmu kewarganegaraan (civics) diistilahkan sebagai kewarganegaraan ekologis atau ecological citizenship. Pada tingkatan dasar, Crane, Matten, dan Moon (2008) menjelaskan bahwa ecological citizenship berkaitan dengan status, hak, dan proses partisipasi yang dilakukan oleh warga negara yang berkaitan dengan lingkungan hidup. Pembangunan dalam konteks lingkungan hidup merupakan salah satu upaya yang penting untuk dilakukan agar masyarakat hidup secara sehat dan damai melalu ketersediaan lingkungan hidupnya. Indonesia sebagai negara berdasar hukum memiliki regulasi yang mendukung terselenggaranya partisipasi masyarakat dalam bidang pembangunan lingkungan hidup. Salah satunya terletak pada Pasal 2 Ayat 1 Undang-Undang Nomor 25 Tahun 2004 tentang Sistem Perencanaan Pembangunan Nasional, menegaskan prinsip pembangunan yang dilakukan harus berpedoman pada prinsip yang ditetapkan, beberapa diantaranya adalah berkelanjutan dan berwawasan lingkungan.

Partisipasi masyarakat dalam bidang lingkungan hidup dapat dilakukan melalui program kampung iklim. Program Kampung Iklim (ProKlim) adalah program berlingkup nasional yang dikelola oleh Kementerian Lingkungan Hidup dan Kehutanan dalam rangka meningkatkan keterlibatan masyarakat. Dalam pertauran menteri tersebut juga disinggung bahwa ProKlim dapat dikembangkan dan dilaksanakan pada wilayah administratif paling rendah setingkat RW atau dusun dan paling tinggi setingkat kelurahan atau desa. Program ini merupakan peluang bagi masyarakat untuk ikut serta dalam mengembangkan kapasitasnya dalam menanggulangi dampak buruk lingkungan. Hal ini pula yang akan dijadikan objek penelityian, karena penting bagi masyarakat untuk ikut serta berpartisipasi menentukan nasib lingkungannya. Penelitian ini sangat penting dan memiliki urgensi lebih untuk segera dilakukan. Kajian mengenai lingkungan hidup dan kontribusi masyarakat dalam pengendalian lingkungan hidup sangat penting untuk segera dilakukan. Melibatkan masyarakat dalam program Dinas Lingkungan Hidup, akan mendorog masyarakat untuk memiliki rasa ingin menjaga dan melanjutkan. Hal inilah yang ingin diketahui dan diberikan tindaklanjut setelah penelitian dilakukan. Melalui penelitian ini diharapkan menjadi referensi dalam mewujudkan tata pemerintah yang baik (good governance) dan masyarakat yang partisipatif (civic participation).

\section{METODE}

Pada penelitian ini peneliti menjelaskan data temuan penelitian dalam rangkaian kata yang dapat menggambarkan data berdasarkan fakta. Jenis penelitian kualitatif yang digunakan dalam penelitian ini adalah jenis penelitian deskriptif fenomenologis. Peneltian jenis ini peneliti mendeskripsikan pengalaman kehidupan manusia tentang suatu fenomen yang 
Jurnal PINUS: Jurnal Penelitian Inovasi Pembelajaran, 7 (1), 2021, Suroto, Dedy Ari Nugroho, Rika Amelia Rafiah

dijelaskan oleh partisipan. Rancangan penelitian kualitatif jenis deskriptif fenomenologis memerlukan landasan filosofi yang kuat dari hasil wawancara mendalam (Creswell, 2016).

Terdapat dua hal yang menjadi karakteristik penelitian jenis deskriptif, antara lain: (1) penelitian terpusat pada suatu masalah yang ada, (2) arah pemikiran yang digunakan dalam penelitian jenis deskriptif adalah mengumpulkan data kemudian diuraikan (dijelaskan) dan kemudian dianalisis, data yang diperoleh menggunakan penelitian wawancara, observasi, dan studi dokumen yang relevan. Tujuan penelitian dengan jenis deskriptif adalah menjelaskan sifat individu, keadaan suatu objek, dan gejala-gejala yang melekat dalam suatu objek (Nazir, 1983). Berkaitan dengan penelitian ini, sifat individu, keadaan suatu objek, dan gejala-gejala yang diteliti mengarah pada fenomena tertentu.

\section{HASIL}

Penelitian ini dilakukan di Kota Banjarmasin, kota yang dikenal dengan julukan Kota Seribu Sungai. Penelitian ini dilakukan antara bulan Februari hingga sampai Agustus 2021, dengan mengacu pada penelitian kultur berbasis ekologis. Kota banjarmasin memiliki kondisi geografis dan topografis yang potensial jika dikelola dengan tepat. Partisipasi masyarakat dan ditaatinya Perda No. 15 Tahun 2016 menjadi kunci untuk membina kesadaran masyarakat mengenai lingkungan di wilayah sungai Banjarmasin. Kota Banjarmasin memiliki luas wilayah 98,46 km2 dan jumlah penduduk kurang lebih 715.733 jiwa dengan kepadatan penduduk 7.118,32 jiwa/km2. Kota Banjarmasin dibelah oleh sebuah sungai besar yaitu sungai Martapura dan terdapat 190 anak sungai dengan kondisi sungai 120 yang masih aktif, 70 sungai tanpa nama dan 18 buah sungai sudah hilang (https://berita.banjarmasinkota.go.id).

Tabel 1 Data Sungai di Banjarmasin

\begin{tabular}{|c|c|c|}
\hline No & Kategori & Jumlah \\
\hline 1 & Anak Sungai & 190 \\
\hline 2 & Sungai Aktif & 120 \\
\hline 3 & $\begin{array}{c}\text { Sungai Tidak } \\
\text { Bernama }\end{array}$ & 70 \\
\hline
\end{tabular}

Berdasarkan hasil survey lapangan yang dilakukan terhadap keberadaan Sungai Miai di lingkungan RT 11 dan 12 dapat disimpulkan dalam kondisi yang layak atau tidak dapat berfungsi dengan baik karena telah terjadi penyempitan, sendemintasi dan terjadi pencemaran air yang disebabkan berdirinya bangunan liar di atas sungai, limbah rumah tangga dan jamban keluarga. Kesadaran masyarakat tehdap fungsi sungai dan air bersih cukup tinggi, akan tetapi karena alasan keterbatasan ekonomi menyebabkan peran masyarakat dalam pengelolaan sungai menjadi tidak optimal.

Strategi yang dipergunakan oleh pemerintah daerah untuk menyukseskan program kampung iklim dan memberikan peluang pada masyarakat untuk berpartisipasi adalah sebagai berikut.

1. Memperkuat kapasitas pemerintah daerah dalam mendorong partisipasi masyarakat.

2. Menjalin kemitraan dengan kementerian/lembaga terkait, 
Jurnal PINUS: Jurnal Penelitian Inovasi Pembelajaran, 7 (1), 2021, Suroto, Dedy Ari Nugroho, Rika Amelia Rafiah

pemerintah daerah, dunia usaha, dan lembaga non pemerintahan.

3. Mendorong komitmen pemerintah.

4. Meningkatkan pengembangan dan penerapan teknologi tepat guna.

5. Memperkuat kapasitas masyarakat dalam melaksanakan upaya adaptasi dan mitigasi perubahan iklim.

6. Mendorong kepemimpinan terciptanya masyarakat.

7. Menyebarluaskan keberhasilan upaya adaptasi dan mitigasi perubahan iklim di tingkat lokal.

8. Mendorong optimalisasi potensi sumber pendanaan.

Adapun berkaitan dengan bentuk partisipasi masyarakat dalam program kampung iklim dibuktikan pada kegiatan sebagai berikut.

1. Masyarakat menyusun program unggulan bidang lingkungan sesuai dengan potensi daerah masingmasing.

2. Masyarakat menyepati program dan mengusulkannya pada pihak Dinas Lingkungan Hidup untuk dapat difasilitasi kegiatannya.

3. Masyarakat memberikan kontribusi tenaga dalam mengupayan program lingkungan di daerahnya.

4. Masyarakat memberikan kontribusi materi untuk memperlancar kegiatan lingkungan pada program kampung iklim.

5. Masyarakat memiliki komitmen untuk melakukan rapat evaluasi bulanan terkait dengan program yang dilakukan.

6. Masyarakat melakukan koordinasi dengan pemerintah daerah secara berkala untuk leporkan kemajuan program kampung iklim yang sedang dilakukan.

Berkaitan data mengenai hambatan yang ditemui oleh pihak yang berkaitan dengan program Kampung Iklim dapat dicermati dalam uraian berikut.

1. Hambatan bagi Dinas Lingkungan Hidup

Berbagai strategi yang diterapkan oleh Pemerintah Daerah kota banjarmasin, tidak sepenuhnya berjalan baik, terdapat hambatan yang mempengaruhi implementasi Program Kampung Iklim. Data atau infomasi yang berkaitan dengan hambatan Pemerintah Daerah Kota Banjarmasin dalam mengembangkan partisipasi masyarakat pada Program Kampung Iklim, dapat dicermati dalam uraian berikut.

a. Rentang waktu yang dialokasikan untuk menyelesaikan program tergolong singkat.

b. Musim penghujan yang sering terjadi di tahap pelaksanaan pembangunan konstruksi menjadikan agenda monitoring di beberapa desa atau kelurahan tertunda.

Beberapa uraian di atas merupakan data tentang hambatan yang ditemui oleh Pemerintah Daerah berkaitan dengan upaya penguatan partisipasi masyarakat dalam Program Kampung Iklim di Kota Banjarmasin. Berbagai hambatan yang ditemui dalam upaya penguatan partisipasi masyarakat dalam Program Kampung Iklim perlu ditanggulangi agar tujuan penyelenggaraan program secara kolaboratif dapat tercapai. Pemerintah Daerah memiliki wewenang untuk menyelenggarakan 
Jurnal PINUS: Jurnal Penelitian Inovasi Pembelajaran, 7 (1), 2021, Suroto, Dedy Ari Nugroho, Rika Amelia Rafiah

berbagai strategi peningkatan partisipasi masyarakat dengan tetap mengantisipasi berbagai kemungkinan terjadinya hambatan.

2. Hambatan bagi masyarakat Kota Banjarmasin

Beberapa hambatan yang timbul dari sisi masyarakat Kota Banjarmasin dapat diamati dalam rincian berikut.

a. Terbatasnya dana bantuan yang hanya bisa digunakan untuk kebutuhan Program Kampung Iklim.

b. Kelompok Masyarakat di awal implementasi

Program

Kampung Iklim belum bisa berkoordinasi dengan baik dengan Pemerintah Daerah Kota Banjarmasin.

c. Cuaca menjadi hambatan masyarakat untuk berpartisipasi dalam tahap pelaksanaan Program Kampung Iklim.

d. Masyarakat di beberapa desa atau kelurahan terhambat partisipasinya karena jadwal gotong royong bertepatan dengan hari masuk kerja.

\section{PEMBAHASAN}

Program Kampung Iklim menjadi salah satu alternatif pembinaan partisipasi masyarakat dalam program pengendalian lingkungan hidup. Pembahasan pada jurnal ini mengacu pada 3 hal, (1) Strategi Pemerintah Kota Banjarmasin dalam upaya penguatan Kewarganegaraan Ekologis pada Program Kampung Iklim, (2) Bentuk partisipasi masyarakat dalam upaya penguatan Kewarganegaraan Ekologis pada Program Kampung Iklim,
(3) hambatan bagi Pemerintah Kota Banjarmasin dan masyarakat Kota Banjarmasin dalam upaya penguatan Kewarganegaraan Ekologis dalam Program kampung iklim. Selanjutnya, pembahasan diuraikan sebagai berikut.

1. Strategi Pemerintah Kota Banjarmasin dalam upaya penguatan Kewarganegaraan Ekologis pada Program Kampung Iklim

Adapun strategi yang dilakukan oleh Pemerintah Kota Banjarmasin mengacu pada siklus perencanaan strategi yang dikembangkan oleh Smith dan Pangsapa sebagai berikut.

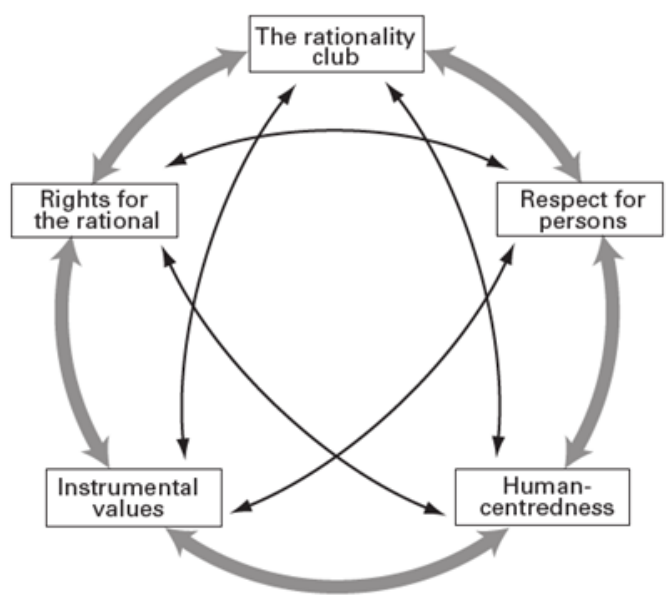

Gambar Pendekatan Anthropocentric (Sumber: Smith dan Pangsapa, 2008)

Berdasarkan pendekatan di atas, secara garis besar diwujudkan dalam 8 strategi unggulan sebagai berikut.

a. Memperkuat hubungan atau kapasitas pemerintah. Strategi ini berkaitan dengan adanya peningkatan kapasitas pemerintah daerah dalam mengembangkan partisipasi masyarakat. Hal ini berkaitan dengan teknis bagaimana pemerintah daerah mampu 
Jurnal PINUS: Jurnal Penelitian Inovasi Pembelajaran, 7 (1), 2021, Suroto, Dedy Ari Nugroho, Rika Amelia Rafiah

memberikan teladan dari kapasitas yang dimiliki.

b. Menjalin kemitraan.

Kemitraan ini berkaitan dengan pendampingan secara teknis dan juga pendanaan yang bisa diberikan oleh pihak mitra untuk memperlancar kegiatan dalam prohgram kampung iklim.

c. Mendorong rasa serta komitmen. Strategi ini berkaitan dengan komitmen pemerintah dan masyarakat dalam memberikan komitmennya untuk mengusulkan dan melakukan program terarah baik di tingkat pusat maupun daerah.

d. Meningkatkan pengembangan dan penerapan teknologi tepat guna. Pada strategi ini dilakukan oleh dinas lingkungan hidup dengan memberikan sosialisasi mengenai informasi terbaru pengembangan lingkungan dengan bersumber pada penggunaan teknologi.

e. Memperkuat apasitas masyarakat. Pada strategi ini berkaitan dengan upaya memberikan pengetahuan dan keterampilan untuk membuat masyarakat menjadi mau dan mampu untuk berkontribusi pada program kampung iklim.

f. Mendorong terciptanya kepemimpinan di tingkat masyarakat. Pada strategi ini pemerintah daerah mengupayakan kaderisasi di tingkat masyarakat, sehingga inisiatif timbul dari tingkat masyarakat untuk setiap langkah dan program yang akan dilakukan.

g. Menyebarluaskan

keberhasilan mitigasi. Pada strategi ini lebih berkaitan pada pemberian motivasi mengenai tingkat keberhasilan yang dilakukan oleh setiap daerah.

h. Mendorong optimalisasi potensi sumber pendanaan. Pada strategi ini berkaitan dengan pendanaan yang bisa diberikan untuk mewujudkan pola dan kegiatan kampung iklim yang berkualitas.

Berkaitan dengan strategi yang dilakukan dalam pembahasan di atas adanya sinergitas antara pemerintah daerah dengan masyarakat menjadi kunci keberhasilannya. Terdapat beberapa hal yang dapat dilakukan untuk senantiasa memberikan dampak baik bagi keberhasilan program pengendalian lingkungan.

2. Bentuk partisipasi masyarakat dalam upaya penguatan Kewarganegaraan Ekologis pada Program Kampung Iklim.

a. Masyarakat menyusun program unggulan bidang lingkungan sesuai dengan potensi daerah masing-masing.

Masyarakat di Kota Banjarmasin melakukan penyusunan program lingkungan dengan prinsip partisipatif, hal ini dibuktikan dengan rapat rutin yang diikuti masyarakat untuk mempersiapkan program yang diterapkan dalam program lingkungan hidup.

Bentuk partisipasi masyarakat dalam hal ini adalah partisipasi dalam bentuk pemikiran dan partisipasi rapat terbatas yang dilakukan. 
Jurnal PINUS: Jurnal Penelitian Inovasi Pembelajaran, 7 (1), 2021, Suroto, Dedy Ari Nugroho, Rika Amelia Rafiah

b. Masyarakat menyepakati program dan mengusulkannya pada pihak Dinas Lingkungan Hidup untuk dapat difasilitasi kegiatannya. Program yang telah dirundingkan di tingkat masyarakat di dasarkan pada kesepakatan bersama yang kemudian menghasilkan kebulatan keputusan mengenai program lingkungan hidup yang sesuai dengan kebutuhan masyarakat dan diusulkan atau diajukan kepada Dinas Lingkungan Hidup Kota Banjarmasin. Pada tahap ini, masyarakat berpartisipasi dalam hal ide/pemikiran dari masyarakat mengenai program.

c. Masyarakat memberikan kontribusi tenaga dalam mengupayan program lingkungan di daerahnya. Masyarakat Kota Banjarmasin menjalankan kegiatan dengan mengedepankan prinsip gotong royong. Partisipasi yang diberikan tidak hanya dalam bentuk tenaga atau fisik ketika menjalankan program lingkungan hidup, secara berkala masyarakat juga mengadakan pertemuan untuk memberikan edukasi kepada generasi muda mengenai kegiatan yang dilakukan.

d. Masyarakat memberikan kontribusi materi untuk memperlancar kegiatan lingkungan pada program kampung iklim. Pada saat gotongroyong berlangsung masyarakat juga memberikan kontribusi materi secara sukarela. Kontribusi materi yang diberikan contohnya adalah bahan material yang dibunakan untuk membangun sarana lingkungan hidup. Terdapat pula masyarakat yang memberikan snack untuk masyarakat yang sedang bergotongroyong.

e. Masyarakat memiliki komitmen untuk melakukan rapat evaluasi bulanan terkait dengan program yang dilakukan. Masyarakat Kota Banjarmasin memberikan kongtribusi secara nyata dalam melakukan evaluasi bersama untuk meningkatkan kualitas program lingkungan hidup. Kegiatan ini dilakukan bulanan di tempat ketua RT tempat program tersebut dilakukan.

f. Masyarakat melakukan koordinasi dengan pemerintah daerah secara berkala untuk leporkan kemajuan program kampung iklim yang sedang dilakukan. Tim pemantauan dari Dinas Lingkungan Hidup selalu melakukan kontrol terhadap pelaksanaan program, Masyarakat dapat memanfaatkan nomentum tersebut untuk mendapatkan evalusi dan memperbaiki program secara bersama-sama.

3. Hambatan yang ditemui dalam pelaksanaan Program Kampung Iklim.

Berkaitan data mengenai hambatan yang ditemui dalam pelaksanaan program kampung iklim dapat dicermati dalam uraian berikut.

a. Hambatan bagi Dinas Lingkungan Hidup

Berbagai strategi yang diterapkan oleh Pemerintah Daerah kota banjarmasin, tidak sepenuhnya berjalan baik, terdapat hambatan yang mempengaruhi implementasi Program Kampung Iklim. Data 
Jurnal PINUS: Jurnal Penelitian Inovasi Pembelajaran, 7 (1), 2021, Suroto, Dedy Ari Nugroho, Rika Amelia Rafiah

atau infomasi yang berkaitan dengan hambatan Pemerintah Daerah Kota Banjarmasin dalam mengembangkan partisipasi masyarakat pada Program Kampung Iklim, dapat dicermati dalam uraian berikut.

1) Rentang waktu yang dialokasikan untuk menyelesaikan program tergolong singkat.

Setiap masyarakt
memiliki kemampuan
berbeda dalam menyerap
materi tentang partisipasi.
Oleh karenar itu,
diperlukan alokasi waktu
yang lebih untuk
menyelenggarakan
kegiatan sosialsiasi dan
pelatihan. Secara
terperinci hambatan
tersebut dinyatakan dalam
kesempatan wawancara
bahwa hambatan yang
dialami adalah waktu yang
dirasa terlalu singkat
untuk menumbuhkan
komitmen dan
pengetahuan masyarakat
untuk berpartisipasi. Hal
tersebut dikarenakan
setiap orang memiliki
daya serap berbeda
terhadap berbagai
informasi sehingga waktu
yang dialokasikan
semestinya lebih.
Informasi bahwa waktu
yang diperlukan untuk
menumbuhkan atau

menguatkan partisipasi masyarakat tergolong singkat karena pada pertengahan tahun sudah harus dipersiapkan untuk tahu tentang teknis pelaksanaan program Kampung Iklim.

2) Musim penghujan yang sering terjadi di tahap pelaksanaan

pembangunan konstruksi menjadikan agenda monitoring di beberapa desa atau kelurahan tertunda.

Musim penghujan yang berkepanjangan, merupakan faktor penghambat yang seringkali tidak selaras dengan agenda monitoring yang telah dialokasikan Pemerintah Daerah. Kegiatan monitoring dari Pemerintah Daerah sering kali disebut uji petik. Agenda monitoring biasanya telah direncanakan dengan sistematis oleh Pemerintah Daerah dan dibuat secara terjawal, sehingga jika dalam satu kesempatan minitoring tidak bisa ditepati karena persoalan cuaca maka Pemerintah Daerah perlu melakukan penjadwalan ulang (reschedule). Agenda monitoring merupakan 
Jurnal PINUS: Jurnal Penelitian Inovasi Pembelajaran, 7 (1), 2021, Suroto, Dedy Ari Nugroho, Rika Amelia Rafiah

unsur penting yang perlu dilakukan oleh Pemerintah Daerah, sebagai salah satu kegiatan menjalin kolaborasi dengan masyarakat, dan memastikan kegiatan pembangunan dilakukan secara partisipatif.

Hambatan yang berkaitan dengan cuaca merupakan hambatan yang dapat terjadi dalam kesempatan apapun. Pernyataan tentang hambatan cuaca sebagai hambatan dalam tahap monitoring, faktor cuaca membuat beberapa agenda mengalami penundaan dan harus reschedule. Musim penghujan yang berkepanjangan juga membuat beberapa agenda kolaborasi terhambat karena Pemerintah Daerah tertunda kunjungannya ke tempat pembangunan.

Berdasarkan

penjelasan di atas, dapat dicermati adanya informasi bahwa cuaca menjadi salah satu hambatan yang berkaitan dengan kegiatan monitoring atau uji petik Program Kampung Iklim di Kota Banjarmasin. Hambatan yang berkaitan dengan cuaca dapat ditanggulangi oleh

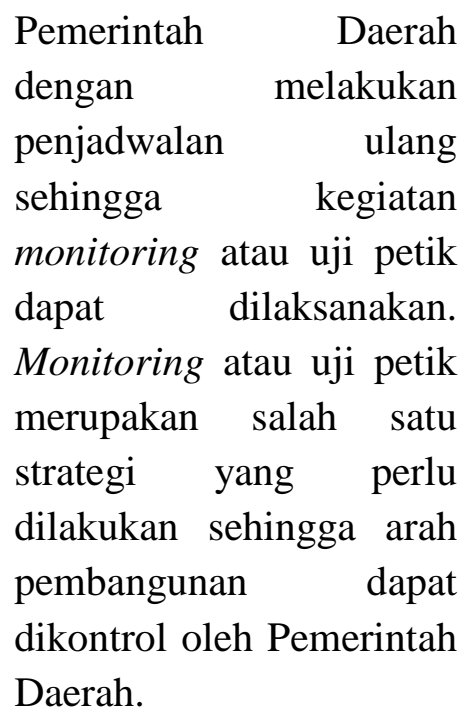

Beberapa uraian di atas merupakan data tentang hambatan yang ditemui oleh Pemerintah Daerah berkaitan dengan upaya penguatan partisipasi masyarakat dalam Program Kampung Iklim di Kota Banjarmasin. Berbagai hambatan yang ditemui dalam upaya penguatan partisipasi masyarakat dalam Program Kampung Iklim perlu ditanggulangi agar tujuan penyelenggaraan program secara kolaboratif dapat tercapai. Pemerintah Daerah memiliki wewenang untuk menyelenggarakan berbagai strategi peningkatan partisipasi masyarakat dengan tetap mengantisipasi berbagai kemungkinan terjadinya hambatan.

2. Hambatan bagi masyarakat Kota Banjarmasin

Beberapa hambatan yang timbul dari sisi masyarakat Kota Banjarmasin dapat diamati dalam rincian berikut.

a. Terbatasnya dana bantuan yang hanya bisa digunakan untuk kebutuhan Program Kampung Iklim. 
Jurnal PINUS: Jurnal Penelitian Inovasi Pembelajaran, 7 (1), 2021, Suroto, Dedy Ari Nugroho, Rika Amelia Rafiah

b. Kelompok Masyarakat di awal implementasi

Program

Kampung Iklim belum bisa berkoordinasi dengan baik dengan Pemerintah Daerah Kota Banjarmasin.

c. Cuaca menjadi hambatan masyarakat untuk berpartisipasi dalam tahap pelaksanaan Program Kampung Iklim.

d. Masyarakat di beberapa desa atau kelurahan terhambat partisipasinya karena jadwal gotong royong bertepatan dengan hari masuk kerja.

Uraian di atas merupakan penerapan Pendidikan Pancasila dan Kewarganegaraan di abad 21, hal tersebut bukan hanya diperlukan dalam konteks kelas dan diajarkan sera teoretik saja, tetapi juga diterapkan di masyarakat sebagai implementasi dari teori yang diperoleh (Dedy; 2017)

\section{KESIMPULAN}

Kesimpulan yang dapat ditarik dari penelitian yang dilakukan, dapat diuraikan sebagai berikut.

1. Strategi Pemerintah Kota Banjarmasin dalam upaya penguatan Kewarganegaraan Ekologis pada Program Kampung Iklim dilakukan dengan pendekatan dialogis dan mengacu pada pemberdayaan masyarakat dan memberi peluang kepada masyarakat untuk berdaya.

2. Bentuk partisipasi masyarakat dalam upaya penguatan Kewarganegaraan Ekologis pada Program Kampung Iklim, dilakukan dengan partisipasi ide atau gagasan dan juga materi.
3. Hambatan bagi Pemerintah Kota Banjarmasin dan masyarakat Kota Banjarmasin dalam upaya penguatan Kewarganegaraan Ekologis dalam Program kampung iklim, berkaitan dengan cuaca, kemauan masyarakat untuk berpartisipasi dan bertepatan dengan hari masuk kerja.

\section{DAFTAR RUJUKAN}

Crane, A., Matten, D., \& Moon, J. (2008). Ecological citizenship and the corporate. Organization and Environment, Volume 21, Number 4, pp 371-389

Creswell, John W. 2016. Research Design Qualitative, Quantitative, and Mixed Methods Approaches.third Edition, Terjemah, Achmad Fawaid, Research Design Pendekatan Kualitatif, Kuantitatif, dan Mixed. Yogyakarta: Pustaka Pelajar.

Dedy Ari Nugroho. (2017). Penguatan Ecological Citizenship melalui penerapan Pendidikan Pancasila dan kewarganegaraan berbasis masyarakat. Jurnal UAD, 18-25.

Johnson, $\underline{\text { C. }}$. (2014).

Local civic participation and

democratic legitimacy: evidence from england and wales. Political Studies, volume 63, Number 4, pp. 765-792

Nazir, Moh. (2013). Metode Penelitian. Bogor: Ghalia Indonesia. 
Jurnal PINUS: Jurnal Penelitian Inovasi Pembelajaran, 7 (1), 2021, Suroto, Dedy Ari Nugroho, Rika Amelia Rafiah

Peraturan Menteri Lingkungan Hidup dan Kehutanan Nomor 84 tahun 2016 tentang Program Kampung Iklim

Peraturan Presiden Nomor 2 Tahun 2015 tentang Rencana Pembangunan Jangka Menengah Nasional Tahun 2015-2019.

Smith, M. J., \& Pangsapa, P. (2008). Environment \& citizenship: integrating justice, responsibility, and civic engagement. London: Zed Books.

Sugiyono. 2010. Metode penelitian kuantitatif kualitatif \& RND. Bandung: Alfabeta.

Sutopo, HB. (2002). Metodologi penelitian. Surakarta: UNS Press.

Undang-Undang Nomor 23 Tahun 2014 Tentang Pemerintahan Daerah.

Undang-Undang Nomor 25 Tahun 2004 tentang Sistem Perencanaan Pembangunan Nasional.

Undang-Undang Nomor 6 Tahun 2014 Tentang Desa.

Wahyuningsih, R. D, dkk. (2012). Publik governance. Surakarta: UNS press.

Uno, Hamzah B. \& Lamatenggo, Nina. Warsita, (2011). Teknologi Komunikasi \& Informasi Pembelajaran. Jakarta: Bumi Aksara.

\author{
Bambang. (2008). Teknologi \\ Pembelajaran: \\ Landasan \\ \&Aplikasinya. Jakarta: Rineka.
}

